\title{
ISOLATION OF COLIPHAGE FROM FEWA LAKE
}

\author{
Subash Adhikari \\ Department of Microbiology \\ Janapriya Multiple Campus, Pokhara, Nepal \\ microsubash@yahoo.com
}

\begin{abstract}
Bacteriophages are host specific viruses targeting only certain types of bacteria. Bacteriophages infecting E-coli are called coliphages. The suspension was prepared from water and tested for the presence of phage. Isolation of bacteriophage by infecting host and experiment isolate coliphage from $45 \mathrm{ml}$ water from Fewa Lake by introducing them to $24 \mathrm{hrs}$ old culture of E-coli followed with centrifugation and filtration. This study was conducted to study virus-bacteria relationship and if phage could be used to remove fecal coliform from Fewa lake.
\end{abstract}

Key words: Bacteriophage, Coliphage, Cytopathic effect, Isolation and Plaque

\section{Introduction}

Viruses are obligate intracellular parasites that require specific host cell for its replication (Carlton 1999). Bacteriophages are viruses that target and reproduce with in bacteria. Phage multiply inside the host (bacteria) by making use of some or all of the host biosynthetic machinery (Elizabeth and Alexandar 2005). They were discovered by British pathologist in London in 1915 by transmissible agent of Micrococcus colonies (Michael et al 2003). Two types of bacteriophages are monovalent and polyvalent. Monovalent phages are specific to one type of bacterial species but polyvalent phages are able to attack two or more bacterial species (Kalmansom and Bronfenbrenner 1942). The phages are commonely named by reference to their host. The phage which attack bacteria Staphylococcus is called staphylophage and those attack Escherichia coli is called coliphage. Generally phages attach to the surface of host by tail fibers. Once attached, the bacteriophage injects its nucleic acid into the bacterium. The phages completes its life cycle in bacterium(host) and escape of matured virus from the host cell places stress on the plasma membrane resulting in the death of bacterium(Prescott et al 2008). 

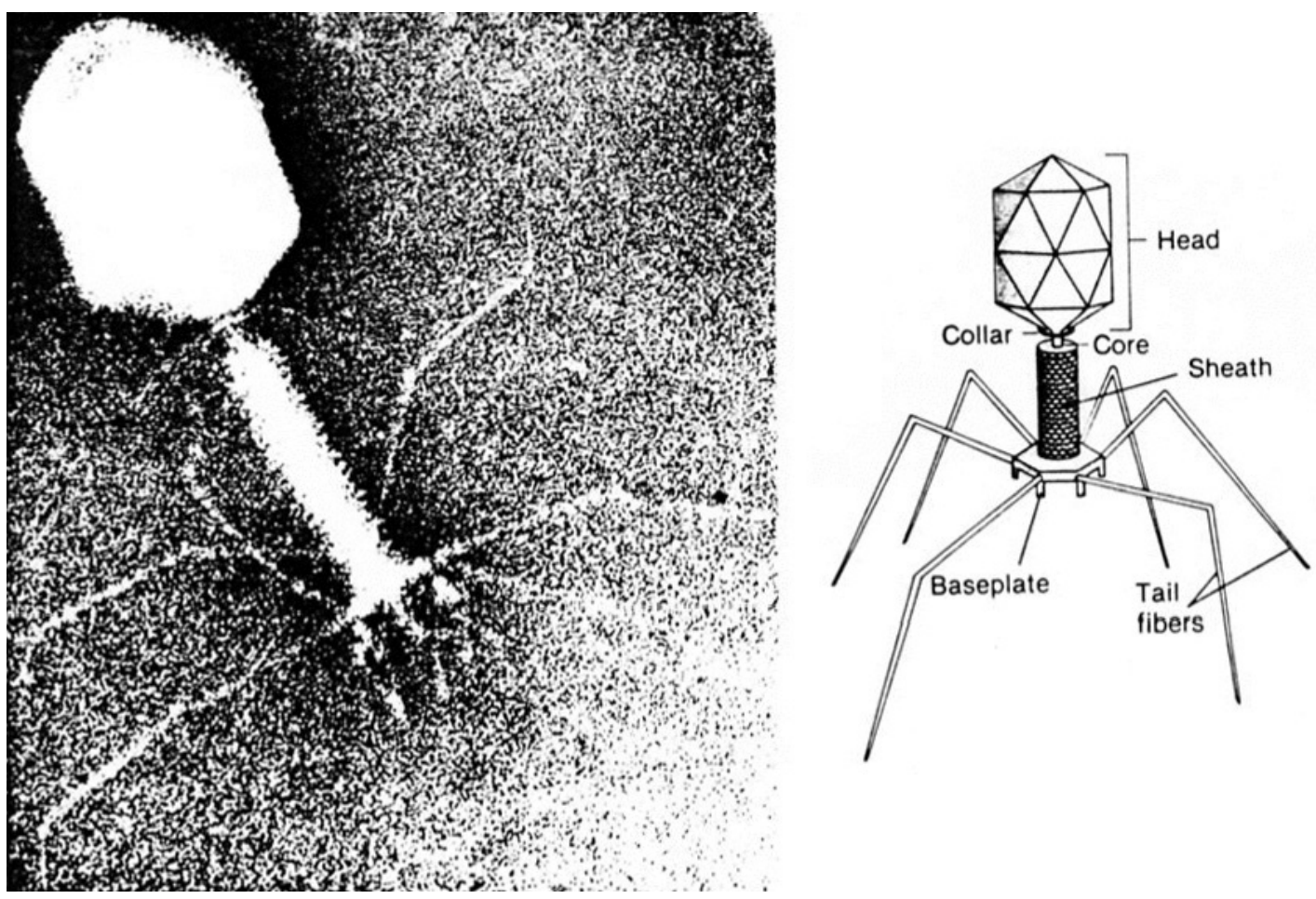

\section{Structure of Bacteriophage}

Bacteriophages are present in soil and even in gut of mammals but isolation from this source is difficult. The simple and easy way to isolate is from sewage and water sample due to their high concentration. Most of phages infects E-coli and these are designated by letter T indicating the types. Seven types have been identified and named as T-even phages (T2,T4 and T6) and T- odd phages(T1,T3,T5 and T7) which have own life cycle in host (Dubey and Maheswori 2012). The phages that penetrate the cells destroy cells producing single plaque in the bacterial lawn. Each plaque can be designated as a plaque forming unit (Pfu) and used to quantitate the number of infective phage particle in the culture (Cappuccino and Sherman 2009).

\section{Materials and Method}

This study was carried from January to March 2013 at Department of Microbiology in Janapriya Multiple campus, Pokhara, Nepal. The study consists of water sample from Fewa lake and following protocol.

\section{Enrichment of water sample}

Lake water was collected from the Fewa Lake in screw capped bottle. $5 \mathrm{ml}$ of bacteriophage nutrient broth, $5 \mathrm{ml}$ of the $E$-coli broth culture and $45 \mathrm{ml}$ of water sample were aseptically added to an appropriately labeled sterile $250 \mathrm{ml}$ Erlenmeyer flask and incubated at $37^{\circ} \mathrm{C}$ for $24 \mathrm{hrs}$ (Dubey and Maheswori 2012). 


\section{Filtration of sample}

Following incubation, phage infected culture was poured into several centrifuge tubes and centrifuged at $2500 \mathrm{rpm}$ for $20 \mathrm{mi}$ to remove residue. Supernatant was decanted into a $125 \mathrm{ml}$ flask and filtered through membrane filter $(0.45 \mathrm{~mm})$ connected with vacuum pump to remove bacterial cells (Dubey and Maheswori 2012).

\section{Isolation of coliphage}

Soft tryptone agar was melted by placing the six tubes in boiling water bath and cooled to $45^{\circ} \mathrm{C}$. Six tryptone agar plates and Six tryptone agar tubes were labeled 1-6 respectively. Using sterile $1 \mathrm{ml}$ pipette, $0.1 \mathrm{ml}$ of the $E$-coli culture was aseptically added to all the soft molten agar tube and one, two, three, four and five drops of the filtrates were added aseptically to respectively labeled molten soft agar tubes except sixth tubes. Each tube of soft agar were poured and mixed into appropriately labeled agar plates and allowed to harden. Sixth tryptone agar tubes was not inoculated with sample which was considered as control. All the plates were incubated in an inverted position for $24 \mathrm{hrs}$ at $37^{\circ} \mathrm{C}$ and were observed for plaque formation which were indicative of the presence of coliphages in the culture (cappuccino and sherman 2009).

\section{Result and discussion}

Phage was isolated from lake water plated with bacteria $(E$-coli) which served as host for coliphage. The presence of clear zone or plaques in all plates except sixth plate after suitable inoculation over lawn culture of bacteria indicate the presence of bacteriophage $($ Table -1$)$. The plaques caused by phages varies in size and are characterized by the circular cone. After incubating for $24 \mathrm{hrs}$ clearing or plaque formation was seen in agar plates. These plaque formations indicate bacterial lyses or presence of bacteriophage in the Nutrient Agar plates (Ananthanarayan and Panikers 2011). Plaques were seen in all the tubes except sixth tube which was considered as control for the experiment. The plaques were maximum in fourth and fifth plates. The sample contained virus which was grown on lawn of $E$-coli. The morphology of plaque may be different with bacteriophage, host and environmental condition. This bacteriophage carry its life cycle in host (E-coli) and show cytopathic effect in host .The result indicate presence of coliphage in fewa lake. Water in fewa lake indicate presence of coliphage which may be from different sources and this may be influenced by season and environment in lake. This coliphage may also spread throughout lake during movement of water which destroy fecal coliform present in Fewa lake that arises from different sources preventing spread of coliform.

Table-1. Formation of Plaques in plates

\begin{tabular}{|l|c|c|}
\hline SN & No of Plates & Formation of Plaque \\
\hline 1 & 1 & + \\
\hline 2 & 2 & + \\
\hline 3 & 3 & + \\
\hline 4 & 4 & + \\
\hline
\end{tabular}




\begin{tabular}{|l|l|c|}
\hline 5 & 5 & + \\
\hline 6 & 6 & - \\
\hline
\end{tabular}

Abbreviations:

$+=$ Presence of Plaque, $-=$ Absence of Plaque

\section{Conclusion}

The host specificity of virus offer an enticing technology for fighting infection caused by bacteria or for the treatment of environment contaminated with pathogenic bacteria. This research concludes that phage can be used to treat against bacterial infection or contamination in environment. Moreover this research is informative regarding virus bacteria relations and phage can be used to remove fecal coliform from fewa lake. This study also became get way for use of viral therapy to treat infection in plants, aqua culture, fish and humans (Sulakvelidze and Burrow 2005) because this virus cause lyses of host cells and cause cytopathic effect. So phage can be used in treatment of bacterial infection unlike broad spectrum antibiotics. The plaque formation unit can also be calculated relating this research. Moreover sample may be taken from different areas of lake for further confirmation comparing the plaque formation unit from different areas.

\section{Acknowledgements}

I wish to extend my sincere thanks to Janapriya Multiple Campus for letting me the use of laboratory facilities needed in accomplishing this study. Similarly, I would like to thank Professor Vikash Kumar K.C for his continuous assistance during the investigation period and report writing. Special thanks to Namita Poudel for her support during research.

\section{References}

Anantharayan R and Panikers CK (2011). Textbook of Microbiology, eighth edition. Universities Press India private limited.

Carlton R M (1999) "Phage Therapy: past History and future prospects". Archivum Immunologiae at Therapie Experimentalis 47:267-74.

Capuccino Jame G and Sherman N (2009). Microbiology A Laboratory Manual Seventh edition, Dorling Kindersley India Ltd.

Dubey RC and Maheshwori DK (2012). A Textbook of Microbiology Seventh edition, S. Chand and Company.

Dubey RC and Maheshwori DK (2012). Practical Microbiology Third edition, S Chands and Company ltd.

Elizabeth K and Alexander S (2005). Bacteriophage in biology and application. CRC Press, Boca Rutan FL, PP 29-66.

Guttman B, Raya R and Kuller E (2005), Basic Phage Biology In: Bacteriophage Biology and application. CRC Press, Boca Rutan FL, pp.29-66.

Kalmansomo G and Bronfenbrenner J (1942). Evidence of serological heterogeneity of 
polyvalent pure line bacteriophage

Madgan MT and Martinko JM (2006). Brock Biology of Microorganism Eleventh edition, USA. Pearson prentice Hall, Pearson Education, Inc.

Michael TM, John MM and Jack P (2003). Brock biology of microorganism. Prentice Hall, USA.

Prescott, Harley and Klein (2008) Microbiology. Seventh edition, Mc Graw Hill.

Sulkveldize A and Barrow P (2005), Phage Therapy in Animals an Agribuiness. In: Bacteriophage Biology and application CRC Press, Boca Rutan pp 335-380.

Tortora G,Funke R and Case C (1995).Microbiology An Introduction Ninth edition, Pearson/Benjamin Cummings Publishing Co Inc. 